\title{
Peningkatan Keterampilan Sosial melalui Penerapan Model Fan N Pick dan Inside Outside Circle di Sekolah Dasar
}

\author{
Agria Golda Vegetari ${ }^{1}$, Utami Widiati ${ }^{2}$, Budi Eko Soetjipto ${ }^{3}$ \\ ${ }^{1}$ Pendidikan Dasar-Universitas Negeri Malang \\ ${ }^{2}$ Pendidikan Bahasa Inggris-Universitas Negeri Malang \\ ${ }^{3}$ Manajemen-Universitas Negeri Malang
}

\begin{tabular}{l}
\hline INFO ARTIKEL \\
\hline Riwayat Artikel: \\
Diterima: 01-04-2019 \\
Disetujui: $17-10-2020$ \\
\hline
\end{tabular}

\section{Kata kunci:}

social skills;

Fan N Pick model;

inside outside circle model;

keterampilan sosial;

model Fan N Pick;

model inside outside circle

\author{
Alamat Korespondensi: \\ Agria Golda Vegetari \\ Pendidikan Dasar \\ Universitas Negeri Malang \\ Jalan Semarang 5 Malang \\ E-mail: avegetary@gmail.com
}

\begin{abstract}
ABSTRAK
Abstract: This study aims to determine the increase in social skills of fifth grade students through the implementation of the Fan N Pick and Inside Outside Circle models. This type of research uses a type of classroom action research with a qualitative approach. The research subjects in this study were students of Banyuajuh 2 Kamal Primary School with a total of 20, namely 8 male students and 12 female students. Data collection of students' social skills using observation. The results of this study indicate that the implementation of the Fan N Pick and Inside Outside Circle models can improve the social skills of class $\mathrm{V}$ students. This can be proven by the increase in students' social skills, namely in the first cycle reached $74.2 \%$ and the second cycle reached $81.8 \%$, so Social skills of class V students in the second cycle increased $7.6 \%$ compared to cycle I.

Abstrak: Penelitian ini bertujuan untuk mengetahui peningkatan keterampilan sosial peserta didik kelas V melalui penerapan model Fan N Pick dan Inside Outside Circle Jenis penelitian ini menggunakan jenis Penelitian Tindakan Kelas dengan pendekatan kualitatif. Subjek penelitian pada penelitian ini adalah peserta didik SD Negeri Banyuajuh 2 Kamal dengan jumlah 20 yaitu 8 peserta didik laki-laki dan 12 peserta didik perempuan. Pengumpulan data keterampilan sosial peserta didik menggunakan observasi. Hasil penelitian ini menunjukkan bahwa penerapan model Fan N Pick dan Inside Outside Circle dapat meningkatkan keterampilan sosial peserta didik kelas V. Hal tersebut dapat dibuktikan dengan meningkatnya keterampilan sosial peserta didik yaitu pada siklus I mencapai $74.2 \%$ dan siklus II mencapai $81,8 \%$ sehingga keterampilan sosial peserta didik kelas $\mathrm{V}$ pada siklus II meningkat 7,6\% dibandingkan siklus I.
\end{abstract}

Salah satu tujuan dari sistem pendidikan saat ini adalah untuk mengembangkan dan mengubah cara belajar peserta didik. Pembelajaran kooperatif dinilai dapat mengembangkan keterampilan sosial peserta didik, melatih tanggung jawab dan kemandirian peserta didik. Pembelajaran dilakukan berkelompok sehingga dapat mencakup aspek-aspek keterampilan sosial, seperti berkomunikasi, membangun dan memelihara kepercayaan, memberikan kepemimpinan dan dapat mengendalikan diri ketika ada suatu masalah (Asoodeh, Asoodeh, \& Zarepour, 2012). Ketika pembelajaran kooperatif diterapkan di sekolah dasar akan terjadi proses pembelajaran interaktif antara peserta didik dan guru. Pembelajaran interaktif yaitu berpusat pada peserta didik yang merupakan pembelajaran aktif. Pembelajaran aktif mengharuskan peserta didik mengendalikan pembelajaran mereka dengan membangun pengetahuan mereka sendiri (Marioara, 2015).

Pada kurikulum 2013 pembelajaran dilakukan secara tematik, peserta didik lebih banyak melakukan kegiatan bersamasama dengan teman sekelasnya atau berkelompok satu sama lain. Hal ini tentunya dapat meningkatkan keterampilan sosial peserta didik. Keterampilan sosial dapat dikembangkan saat pembelajaran di kelas dengan menggunakan metode seperti diskusi kelompok, bermain peran, pemecahan masalah, dan brain storming. Kelompok merupakan suatu sarana untuk berkomunikasi dalam memproses keterampilan peserta didik. Keterampilan sosial peserta didik dapat berkembang dengan baik jika terdapat interaksi antar individu dengan kelompok (Effendi, Soetjipto, \& Widiati, 2016). Keterampilan sosial dibutuhkan bagi peserta didik di sekolah dengan bekerjasama secara kooperatif sehingga peserta didik mampu mencapai kesuksesan di sekolah maupun di lingkungan sosialnya. 
Keterampilan sosial sebagai perilaku yang mampu memprediksi hasil keluaran sosial yang penting dalam situasi tertentu seperti penerimaan teman sebaya atau popularitas, penilaian perilaku penting lainnya, atau perilaku sosial lainnya yang dikenal untuk mengkolerasikan secara konsisten dengan penerimaan teman sebaya atau penilaian perilaku penting lainnya (Gresham, Elliott, Vance, \& Cook, 2011). Terdapat beberapa manfaat dari pembelajaran kooperatif yaitu prestasi akademik, harga diri dan kepercayaan diri sebagai pembelajar, hubungan antar kelompok yang heterogen dan tidak membeda-bedakan antar ras, suku dan budaya, penerimaan sosial peserta didik, kemampuan menggunakan keterampilan sosial (Bernero, 1992).

Masalah yang terjadi di beberapa sekolah dasar masih sebaliknya, masih ada sekolah dasar yang hanya menekankan keberhasilan pada hasil belajar peserta didik yaitu pada ranah kognitif saja, sehingga keterampilan sosial peserta didik dinilai masih kurang. Hal ini tentunya berdampak buruk pada interaksi antar peserta didik, keterampilan berbicara, pengungkapan perasaan, permasalahan dan pendapat peserta didik. Ketika keterampilan sosial peserta didik tidak diasah maka akan merugikan bagi peserta didik itu sendiri karena akan terjadi masalah-masalah sosial yang akan dihadapi peserta didik. Dari observasi awal dan wawancara yang telah dilakukan bertempat di SD Negeri Banyuajuh 2 Kamal dapat diketahui bahwa pembelajaran tematik berjalan lancar meskipun guru masih menggunakan metode pembelajaran konvensional yang lebih banyak melibatkan guru disetiap proses pembelajaran. Akan tetapi hasil belajar yang dicapai kurang maksimal sehingga perlu adanya perubahan untuk meningkatkan hasil belajar peserta didik. Interaksi yang terjalin baik peserta didik dengan peserta didik lainnya maupun dengan guru atau orang lain masih sangat kurang karena komunikasi yang terjalin masih satu arah sehingga perlu meningkatkan keterampilan sosial peserta didik.

Proses kegiatan belajar mengajar masih sering dilakukan dengan model pembelajaran yang berpusat kepada guru. Guru masih sering menggunakan metode pembelajaran konvensional dalam pembelajaran. Dalam hal ini guru secara terus menerus memberikan materi dengan menggunakan metode konvensional yaitu transfer ilmu secara satu arah, peserta didik tidak berkesempatan untuk menemukan pengetahuannya sendiri sehingga bersifat tidak efektif. Pembelajaran juga sering dilakukan individual, tidak adanya interaksi antara siswa satu dengan yang lain sehingga kemampuan sosial peserta didik untuk berinteraksi dengan temannya kurang. Hal ini dapat berdampak buruk yaitu rendahnya keterampilan sosial peserta didik. Ketika keterampilan sosial peserta didik rendah banyak dari peserta didik takut untuk berbicara dengan lawan bicaranya (teman/guru) baik ketika bermain ataupun mengemukakan pendapatnya (Tyabaev, Sedelnikova, \& Voytovich, 2015).

Permasalahan yang timbul akan memberikan dampak yang buruk terhadap keterampilan sosial sehingga keterampilan sosial yang dimiliki peserta didik rendah dan kurang berkembang. Jika keterampilan peserta didik kurang baik maka dapat menyebabkan peserta didik kurang mampu dalam menjalin hubungan yang baik dengan orang lain dan cenderung memiliki hubungan yang tidakmenyenangkan dengan orang lain atau teman sebaya dan mendapat umpan balik yang negatif. Karakteristik peserta didik yang memiliki keterampilan sosial rendah dapat dilihat dari peserta didik tidak dapat menyesuaikan perilakunya sesuai dengan situasi dan kondisi, sulit untuk mengendalikan tingkah laku agresif, serta perilaku sosial tidak dapat diterima oleh orang lain.

Guru harus dapat mengembangkan model pembelajaran yang digunakan sehingga tidak monoton dengan model yang bepusat pada guru (teacher centered). Dalam suatu pembelajaran khususnya pada Kurikulum 2013 mempunyai komponen penting yang harus diperhatikan oleh guru yaitu menentukan model pembelajaran yang digunakan ketika proses kegiatan belajar mengajar berlangsung. Dengan pemilihan model pembelajaran yang tepat peserta didik dapat meningkatkan hasil belajar dan keterampilan sosial dalam belajar peserta didik. Konsep tersebut diharapkan hasil pembelajaran lebih bermakna bagi peserta didik karena proses pembelajaran yang berlangsung secara alamiah dalam bentuk kegiatan siswa bekerja dan mengalami, bukan mentransfer pengetahuan dari guru ke peserta didik dan membuat pembelajaran berpusat pada peserta didik. Lingkungan pembelajaran yang berpusat pada peserta didik merupakan lingkungan belajar yang menggambarkan metode berpikir tentang belajar dan mengajar yang menekankan tanggung jawab peserta didik dalam kegiatan belajar seperti perencanaan, berinteraksi dengan guru dan peserta didik lainnya. Ini berarti peserta didik memainkan peran penting dan aktif dalam pembelajaran (Aziz et al., 2014).

Permasalahan tersebut dapat diselesaikan dengan menggunakan pemilihan model pembelajaran yang dapat menarik dan membangkitkan motivasi peserta didik dalam belajar peserta didik yaitu salah satunya yaitu dengan menerapkan model cooperative learning. Model pembelajaran kooperatif di dalamnya terdapat beberapa model-model pembelajaran. Setelah melakukan observasi awal peneliti memilih dua model kooperatif yang cocok diterapkan untuk dapat meningkatkan keterampilan sosial dan hasil belajar peserta didik. Model tersebut yaitu Fan N Pick dan Inside Outside Circle yang dikembangkan oleh Spencer Kagan. Kedua model ini diterapkan secara berkelanjutan dan sesuai dengan langkah-langkah / sintaks dari model Fan and Pick dan Inside Outside Circle. Kagan (2009) mengemukakan bahwa model pembelajaran kooperatif Fan N Pick dan Inside Outside Circle merupakan model yang menekankan pada membangun kelas, keterampilan sosial, keterampilan berkomunikasi, membangun pengetahuan, kemampuan prosedur, memproses informasi dan keterampilan berpikir.

Kagan (2009) menjelaskan bahwa model Fan N Pick merupakan model pembelajaran secara berkelompok dengan menggunakan kartu tanya. Didalam kelompok kecil yang dibagi terdapat empat anggota. Anggota pertama yaitu bertugas membawa kartu dan membentuk kartu menyerupai kipas kemudian anggota pertama mengucapkan "ambil kartu" pada anggota ke 2. Anggota kedua yaitu bertugas membacakan pertanyaan yang terdapat pada kartu yang diambil. Anggota ketiga menjawab pertanyaan yang diberikan. Anggota keempat memberikan evaluasi terhadap jawaban anggota ketiga dan memberikan apresiasi. 
Kemudian diulang dengan sintaks yang sama sesuai dengan arah jarum jam hingga kartu yang diberikan habis. Model Fan $N$ Pick ini dirasa sangat menyenangkan karna pembelajaran dilakukan secara berkelompok sehingga terjadi interaksi peserta didik satu dengan yang lain.

Model pembelajaran Inside Outside Circle merupakan model pembelajaran yang melibatkan banyak anggota kelompok. Model Inside Outside Circle ini sebenarnya juga tergolong pembelajaran kolaboratif, mengingat jumlah peserta didik yang terlibat dalam kelompok lebih besar dari enam orang. Langkah-langkah model ini yaitu setengah dari peserta didik di dalam kelas berdiri dan membentuk lingkaran kecil dan menghadap keluar, separuh peserta didik yang lainnya membentuk lingkaran diluar lingkaran pertama menghadap ke dalam. Peserta didik yang ada pada lingkaran kecil berapasangan dengan peserta didik yang ada di lingkaran besar. Guru membagikan kartu pertanyaan pada siswa di lingkaran kecil ataupun di lingkaran besar. Peserta didik yang memegang kartu pertanyaan akan memberikan pertanyaan kepada pasangannya, kemudian jika jawaban yang diberikan benar peserta didik yang memegang kartu pertanyaan memberikan apresiasi dan apabila jawaban salah maka diberikan pembenaran jawaban. Kemudian siswa yang ada pada lingkaran luar berputar searah jarum jam dan berganti pasangan dan diulang kembali sampai bertemu pada pasangan awal.

Keunggulan dalam pembelajaran kooperatif dengan model-model yang dikembangkan oleh Spencer Kagan memberi dampak positif bagi peserta didik dan guru. Dampak positif tersebut diantaranya (1) terjadinya ketergantungan yang positif, (2) adanya pengakuan dalam merespon perbedaan individu, (3) peserta didik dilibatkan dalam perencanaan dan pengelolaan kelas, (4) suasana kelas yang rileks dan tenang, (5) terjadinya hubungan yang hangat dan bersahabat antara peserta didik dan guru, dan (6) memiliki banyak kesempatan untuk mengekspresikan pengalaman emosi yang menyenangkan antar peserta didik (Frianto, Soetjipto, \& Amirudin, 2016).

Penerapan model ini dapat menarik perhatian peserta didik karena model pembelajaran ini berbasis permainan yang menyenangkan dan melibatkan seluruh peserta didik sehingga pembelajaran menjadi aktif. Salah satu keunggulan model Inside Outside Circle ini adalah adanya struktur yang jelas dan memungkinkan peserta didik untuk saling berbagi atau bertukar informasi dengan singkat dan teratur, selain itu peserta didik juga memiliki kesempatan untuk mengolah informasi dan meningkatkan keterampilan berkomunikasi. Permainan dalam model kooperatif dapat membantu peserta didik untuk membentuk budaya berbicara dengan lawan bicaranya (Tyabaev, Sedelnikova, \& Voytovich, 2015).

Penelitian ini masih tergolong baru karena kedua model yang dikembangkan Spencer Kagan ini masih jarang digunakan atau diterapkan di sekolah dasar. Perbedaan dari penelitian sebelumnya terletak pada kolaborasi dua model yang berbeda yaitu Fan N Pick dan Inside Outside Circle dengan konten pelajaran satu subtema yang ada di dalam tema 7 Peristiwa dalam Kehidupan. Berdasarkan uraian diatas, maka dilakukan sebuah penelitian dengan tujuan untuk mengetahui lebih jelas tentang "Peningkatan Keterampilan Sosial Melalui Penerapan Model Fan N Pick dan Inside Outside Circle di SD"

\section{METODE}

Penelitian ini menggunakan jenis penelitian tindakan kelas (Classroom Action Research) dengan pendekatan kualitatif. Terdapat empat tahapan dari penelitian ini yaitu perencanaan (planning), pelaksanaan tindakan (Implementing), Observasi (Observing) dan Refleksi (Reflecting). Berdasarkan observasi dan wawancara awal yang telah dilakukan oleh peneliti kepada wali kelas $\mathrm{V}$ dan peserta didik dapat diketahui bahwa keterampilan sosial peserta didik masih rendah. Subjek penelitian ini adalah peserta didik kelas V SD Negeri Banyuajuh 2 Kamal yang berjumlah 20 peserta didik.

Teknik pengumpulan data pada penelitian ini yaitu menggunakan observasi yang merupakan cara pengumpulan data dengan mengadakan pengamatan terhadap kegiatan yang sedang berlangsung. Observasi keterampilan sosial dilakukan oleh dua observer yaitu guru wali kelas $\mathrm{V}$ sebagai observer pertama dan mahasiswi pendidikan dasar sebagai observer kedua. Kedua observer mengamati keterampilan sosial peserta didik selama pembelajaran berlangsung dengan mengisi pada lembar observasi keterampilan sosial peserta didik kelas V. Terdapat lima rentang skor yang akan diberikan oleh observer yaitu sangat baik, baik, cukup, kurang dan sangat kurang. Prosedur penelitian tindakan kelas ini dilakukan dalam bentuk siklus yang berulang. Penelitian ini menggunakan prosedur penelitian yang mengacu pada alur spiral yang dikembangkan oleh Kemmis \& McTaggart. Di dalam siklus tersebut terdapat empat tahapan penting yaitu planning, acting, observing, dan reflecting.

Tahap pertama yaitu perencanaan yang bertujuan untuk mengidentifikasi, merumuskan, dan menganalisis penyebab masalah sehingga ditemukan suatu pemecahan masalah. Kegiatan pada tahap ini yaitu menyusun RPP, membuat kartu soal Fan $N$ Pick dan Inside Outside Circle, dan membuat lembar observasi keterampilan sosial beserta kisi-kisinya. Tahap kedua yaitu pelaksanaan tindakan dengan tahapan-tahapan yaitu penjelasan materi, penjelasan langkah-langkah model Fan $N$ Pick dan Inside Outside Circle, pembentukan kelompok, pelaksanaan model Fan N Pick (72 menit) dan Inside Outside Circle (56 menit). Tahap ketiga ialah observasi dimana guru dan mahasiswi sebagai observer mencatat peristiwa khusus yang ada selama proses pembelajaran dan mengisi lembar keterampilan sosial yang telah disediakan. Tahap yang terakhir adalah refleksi dimana kegiatan ini bertujuan untuk menganalisis segala sesuatu yang terjadi dan yang telah dilaksanakan atau belum tercapai pada saat pelaksanaannya. Evaluasi data juga diperlukan dalam penelitian ini untuk memaknai hasil tindakan penelitian pembelajaran ketika menerapkan model Fan N Pick dan Inside Outside Circle untuk meningkatkan keterampilan sosial peserta didik kelas V. Kegiatan evaluasi data dilakukan diakhir siklus dengan menganalisis data yang didapat pada setiap akhir siklus. Kriteria keberhasilan tindakan keterampilan sosial peserta didik dengan lima sub komponen yaitu kerjasama, tanggung jawab, empati, ketegasan dan pengendalian diri memiliki target pencapaian rata-rata minimal kelas sebesar $80 \%$. 


\section{HASIL}

Pelaksanaan penelitian dilakukan di SD Negeri Banyuajuh 2 Kamal kelas V dalam dua siklus. Dalam satu siklus terdapat lima pertemuan dengan menggunakan model pembelajaran Fan N Pick dan Inside Outside Circle. Penerapan siklus I dan siklus II mempunyai tahapan yang sama. Pembelaran dalam tiap siklus dilaksanakan dengan model Fan N Pick dan Inside Outside Circle dengan tahapan-tahapan yaitu pertama adalah penjelasan materi yang dilaksanakan oleh guru, dilanjutkan dengan penjelasan langkah-langkah dari model pembelajaran Fan N Pick dan Inside Outside Circle. Kemudian dilanjutkan dengan kegiatan pembentukan kelompok secara berpasang-pasangan sebanyak 4 peserta didik dalam satu kelompok. Selanjutnya adalah pelaksanaan pembelajaran Fan $N$ Pick. Guru membagikan kartu pertanyaan kepada salah satu anggota kelompok. Setelah pelaksanaan kegiatan pembelajaran dengan menggunakan model Fan $N$ Pick guru membentuk kelompok yang lebih besar yaitu jumlah satu kelas di bagi menjadi dua yaitu terbagi atas kelompok luar dan kelompok dalam. Kemudian dilakukan pelaksanaan model Inside Outside Circle yang dilakukan di luar kelas.

Pada kegiatan proses pelakasanaan pembelajaran di siklus I dapat diketahui bahwa pembelajaran berlangsung dengan baik, tetapi terdapat beberapa kendala ketika penerapan model Fan N Pick dan Inside Outside Circle. Kendala-kendala tersebut, yaitu beberapa peserta didik masih terlihat bingung dengan sintaks model Fan N Pick dan Inside Outside Circle, peserta didik masih malu bertanya, beberapa terlihat masih mengganggu temannya, mengejek jawaban teman yang salah dan masih ragu-ragu ketika menjawab pertanyaan yang diberikan oleh temannya. Ketika penerapan model Fan N Pick dan Inside Outside Circle dilaksanakan masih banyak peserta didik yang lupa memberikan apresiasi kepada teman yang menjawab benar ataupun salah. Peserta didik juga masih bingung ketika perputaran searah jarum jam dilakukan dalam penerapan model Fan N Pick dan Inside Outside Circle.

Tabel 1. Hasil Observasi Keterampilan Sosial Peserta Didik Siklus I

\begin{tabular}{cll}
\hline No. & Aspek Penilaian & Presentase \% \\
\hline 1. & Kerjasama & $74.8 \%$ \\
2. & Ketegasan & $71 \%$ \\
3. & Tanggung Jawab & $74.4 \%$ \\
4. & Empati & $75.8 \%$ \\
5. & Pengendalian Diri & $75 \%$ \\
\hline Total Presentase & $\mathbf{7 4 . 2 \%}$ \\
\hline Kriteria & Baik \\
\hline
\end{tabular}

Hasil dari kegiatan observasi keterampilan sosial yang telah dilakukan oleh kedua observer pada siklus I menunjukkan persentase sebesar $74.2 \%$ dengan kriteria baik. Dari perolehan data diatas masih belum mencapai dan belum memenuhi kriteria pencapaian yang telah ditetapkan oleh peneliti yaitu sebesar $\geq 80 \%$. Sehingga masih perlu adanya peningkatan keterampilan dalam kelima aspek yaitu kerjasama, ketegasan, tanggung jawab, empati, dan pengendalian diri.

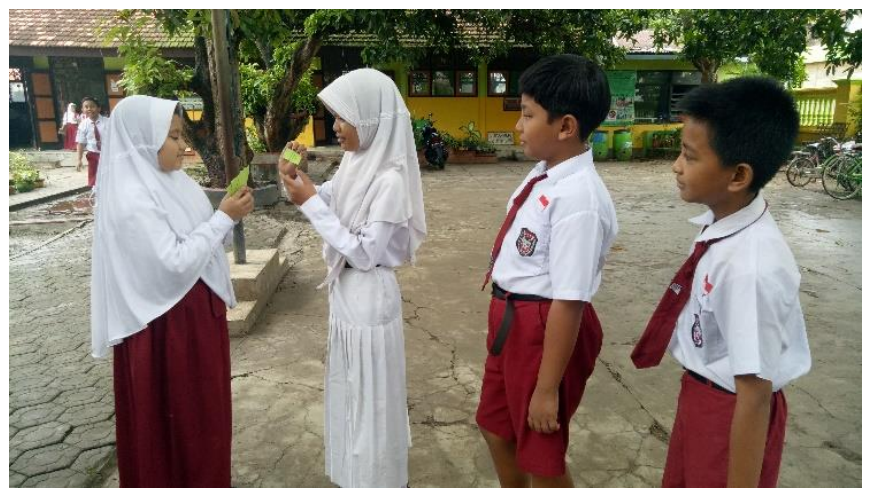

Gambar 1. Penerapan Model Fan N Pick Siklus I

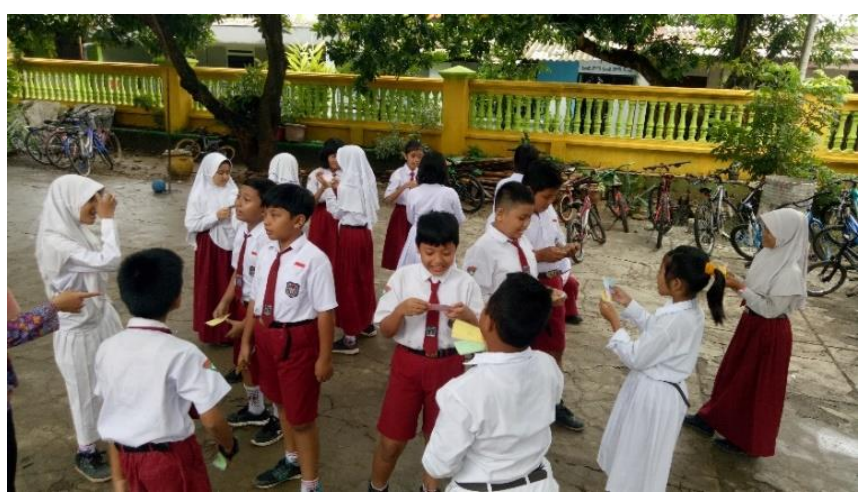

Gambar 2. Penerapan Model Inside Outside Circle Siklus I

Pada penerapan siklus II yang dilaksanakan selama lima pembelajaran dengan menggunakan model Fan N Pick dan Inside Outside Circle dapat diketahui proses pembelajaran berlangsung sangat baik. Terdapat beberapa temuan dari siklus II ini yaitu peserta didik mulai aktif bertanya, peserta didik menunjukkan rasa empati terhadap teman yang ketika proses pembelajaran berlangsung tidak bisa menjawab dengan baik, komunikasi antara peserta didik dengan peserta didik lain dan komunikasi peserta didik dengan guru terjalain dengan baik. Ketika proses pembelajaran dengan model Fan N Pick dan Inside Outside Circle peserta didik memberikan apresiasi satu sama lain untuk menghargai jawaban dari teman. Peserta didik juga terlihat tidak kebingungan lagi tentang sintaks dan perputaran kedua model. 
PENINGKATAN KETERAMPILAN SOSIAL PESERTA DIDIK KELAS V

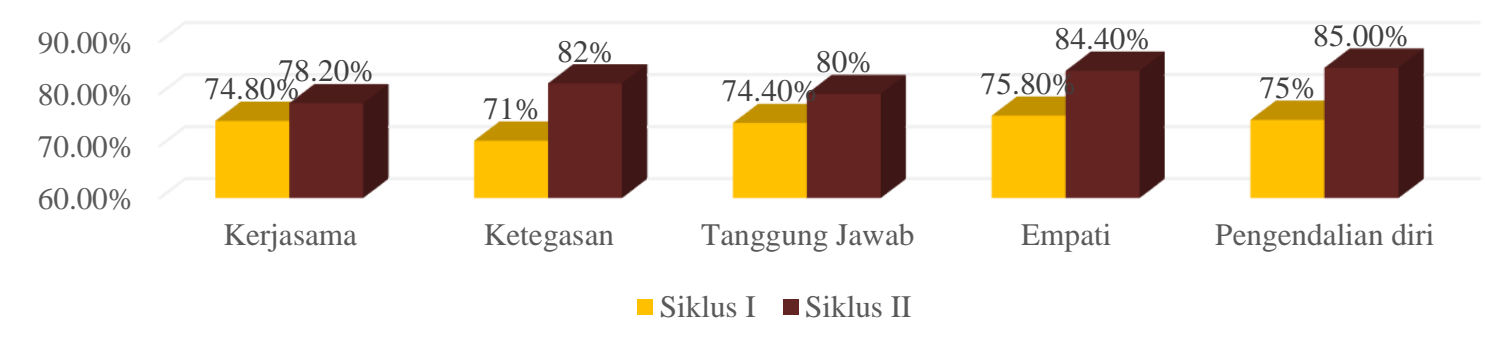

Tabel 2. Hasil Observasi Keterampilan Sosial Peserta Didik Siklus I

\begin{tabular}{clc}
\hline No. & Aspek Penilaian & Presentase \% \\
\hline 1. & Kerjasama & $78.2 \%$ \\
2. & Ketegasan & $82.0 \%$ \\
3. & Tanggung Jawab & $80.0 \%$ \\
4. & Empati & $84.4 \%$ \\
5. & Pengendalian Diri & $85.0 \%$ \\
\hline Total Presentase & $\mathbf{8 1 . 8 \%}$ \\
\hline Kriteria & Sangat Baik \\
\hline
\end{tabular}

Dari hasil data yang diperoleh pada siklus II dapat diketahui model pembelajaran Fan N Pick dan Inside Outside Circle dapat meningkatkan keterampilan sosial peserta didik dimana hasil menunjukkan persentase sebesar $81.8 \%$ dan berada pada kriteria sangat baik. Pada siklus II ini dikatakan berhasil karena telah memenuhi dan mencapai kriteria keberhasilan yang telah ditetapkan oleh peneliti yaitu $\geq 80 \%$ dan ada pada kriteria sangat baik. Pembelajaran pada siklus II juga lebih baik dibandingkan siklus I.

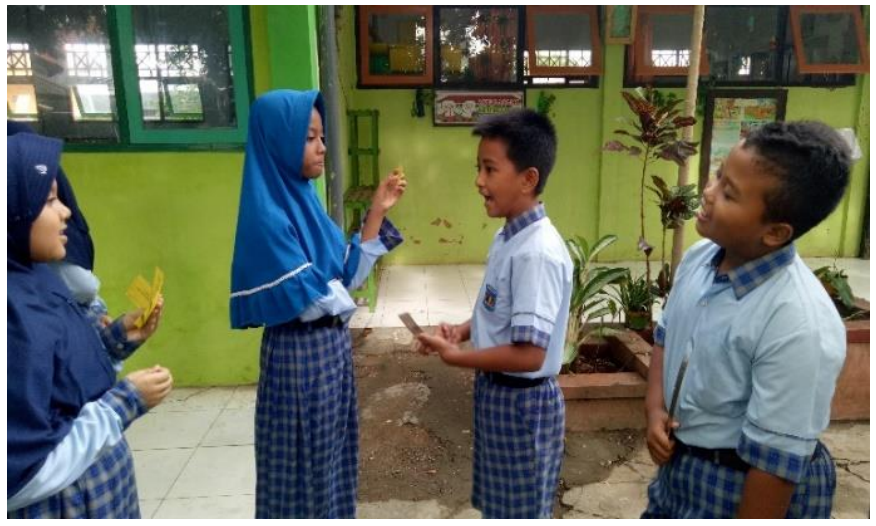

Gambar 3. Penerapan Model Fan N Pick Siklus II

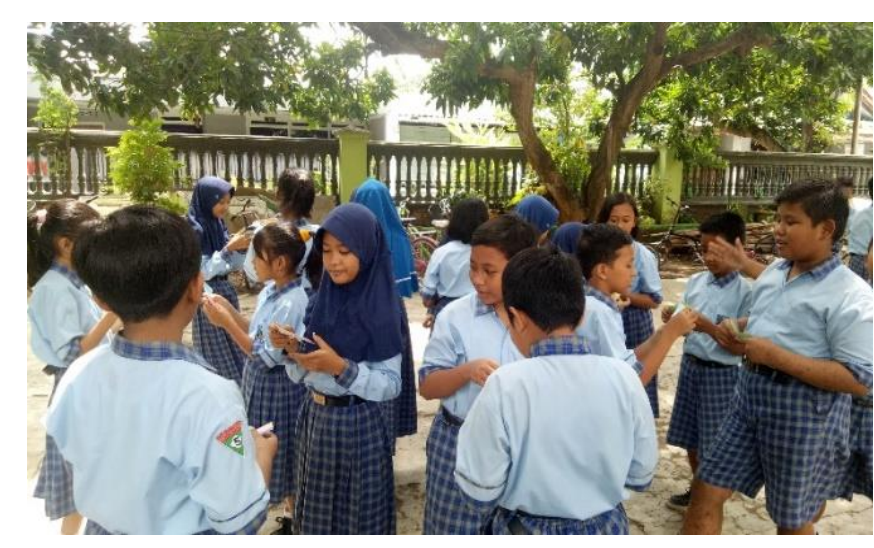

Gambar 4. Penerapan Model Inside Outside Circle Siklus II

Peningkatan keterampilan sosial peserta didik kelas V SD Negeri Banyujuh 2 Kamal terjadi pada siklus II dengan perbaikan dan refleksi pada siklus I. Guru memberikan motivasi yang lebih dan arahan kepada peserta didik ketika melakukan kegiatan pembelajaran dengan menggunakan model Fan N Pick dan Inside Outside Circle. Peningkatan tersebut dapat dilihat pada gambar 1.5 mengenai peningkatan keterampialan sosial peserta didik pada siklus I dan II.

\section{PEMBAHASAN}

Keterampilan sosial peserta didik dapat dikembangkan melalui interaksi yang terjalin antara peserta didik dengan teman sebayanya. Suatu pembelajaran dapat dikatakan efektif apabila menekankan pada pengalaman belajar peserta didik yang ingin mengalami sendiri suatu proses pembelajaran, tingginya rasa ingin tahu peserta didik dan interaksi yang terjalin antar peserta didik dengan teman ataupun guru (Purwaningrum, 2018). Pembelajaran dengan menggunakan model kkoperatif Fan $N$ Pick dan Inside Outside Circle menekankan peserta didik untuk saling bekerjasama dengan anggota kelompoknya. Terdapat lima kriteria pembelajaran kooperatif yaitu ketergantungan positif, akuntabilitas individu, interaksi dua arah, penggunaan 
keterampilan kolaboratif dan penilaian kelompok. Pembelajaran kooperatif juga dapat meningkatkan informasi peserta didik, keterampilan berpikir tingkat tinggi, keterampilan komunikasi dan kepercayaan diri (Kaufman, Felder, \& Fuller, 2000). Pembelajaran dengan menggunakan model kooperatif dapat membantu peserta didik dalam berinteraksi dengan temantemannya, tidak hanya membantu peserta didik dalam belajar, tetapi juga dapat melatih peserta didik untuk memiliki kompetensi berpikir yang baik dan kompetensi sosial sebagai kompetensi untuk mengekspresikan pendapat mereka, menerima saran, dan masukan dari orang lain, kerjasama, solidaritas. Peserta didik tidak lagi sebagai objek pembelajaran, tetapi dapat bertindak sebagai subjek atau tutor teman sebaya (Riyadi, Soetjipto, \& Amirudin, 2016).

Pada pelaksanaan pembelajaran siklus I masih belum maksimal yaitu karena mendapatkan beberapa hambatan dalam pelaksanaannya diantaranya yaitu (a) peserta didik masih ada yang terlihat bingung dengan sintaks atau langkah-langkah model pembelajaran, sehingga penjelasan langkah-langkah lebih baik diulang dua kali diawal kegiatan sehingga peserta didik lebih paham dan tidak terlihat bingung, (b) peserta didik terlihat kurang memperhatikan ketika guru memberikan masukan atau memotivasi peserta didik di akhir pembelajaran, (c) alokasi waktu yang diberikan terkadang masih tidak sesuai dengan perencanaan tindakan, (d) peserta didik masih banyak yang bergurau ketika menjawab pertanyaan, (e) peserta didik sering lupa memberikan apresiasi kepada temannya, (f) ketika melakukan perputaran searah jarum jam peserta didik masih bingung sehingga sering terjadi kesalahpahaman antar peserta didik.

Namun, dari permasalahan pada siklus I dapat diperbaiki pada siklus II sehingga pembelajaran dapat lebih dikondisikan dengan lebih baik. Pembelajaran pada siklus II berlangsung dengan baik yaitu dapat terlihat ketika (a) peserta didik mulai aktif bertanya, (b) menunjukkan rasa empati yang sangat baik kepada teman yang tidak bisa menjawab, (c) memberikan respon yang baik tehadap jawaban dari peserta didik, (d) komunikasi yang terjalin baik antara peserta didik dengan teman dan peserta didik dengan guru, (e) peserta didik tidak merasa bingung dan paham dengan melakukan langkah-langkah kegiatan pembelajaran Fan N Pick dan Inside Outside Circle, (f) Alokasi yang ditetapkan sudah sesuai, (g) bersemangat ketika mengikuti pembelajaran dan sangat antusias ketika model pembelajaran diterapkan karena guru sudah cukup memotivasi peserta didik dengan baik.

Pelaksanaan model Fan N Pick dan Inside Outside Circle dapat dikatakan berhasil karena terlihat adanya interaksi positif antara peserta didik dengan peserta didik lainnya maupun peserta didik dengan guru. Kegiatan yang telah dilakukan dengan menggunakan kedua model tersebut dapat memengaruhi keterampilan sosial peserta didik terutama dalam aspek kerjasama, tanggung jawab, empati, ketegasan dan pengendalian diri. Purwaningrum (2018) mengemukakan bahwa penerapan model pembelajaran kooperatif dibutuhkan proses kerjasama yang berlangsung diantara peserta didik sehingga dapat terlaksana dengan maksimal, menciptakan lingkungan pembelajaran yang berpusat pada peserta didik (student center), dan memberikan kesempatan kepada peserta didik untuk aktif dalam proses pembelajaran. Pada penerapan kedua model terlihat peserta didik kelas V terlihat aktif dalam proses pembelajaran. Peserta didik juga tidak merasa bosan karena pembelajaran tidak dilaksanakan di dalam kelas secara terus menerus dan pembelajaran dilakukan secara berkelompok.

Keterampilan sosial peserta didik dapat diukur dengan menggunakan instrument yaitu lembar observasi keterampilan sosial peserta didik yang diisi oleh dua observer. Mulai dari pembelajaran pada siklus I hingga siklus II observer mengamati pelaksanaan aktivitas keterampilan sosial peserta didik dengan menggunakan instrumen lembar observasi keterampilan sosial yang telah disediakan oleh peneliti. Selain lembar observasi yang diisi oleh observer terdapat pula angket keterampilan sosial peserta didik yang diisi disetiap akhir siklus oleh peserta didik. Terdapat lima aspek penilaian pada lembar observasi keterampilan sosial peserta didik yaitu, (1) kerjasama, (2) ketegasan, (3) tanggung jawab, (4) empati, dan (5) pengendalian diri.

Dari hasil observasi keterampilan sosial peserta didik yang telah diisi oleh kedua observer pada lembar observasi yang telah disediakan memperoleh data yaitu pada siklus I memperoleh hasil sebesar $74.2 \%$ yang menunjukkan kriteria baik. Sedangkan pada siklus II memperoleh hasil sebesar $81.8 \%$ dengan kriteria sangat baik. Dari hasil observasi keterampilan tersebut dapat dikatakan bahwa model pembelajaran Fan N Pick dan Inside Outside Circle dapat meningkatkan keterampilan sosial peserta didik kelas V SD Negeri Banyuajuh 2 Kamal. Hal ini dapat dilihat dari perubahan peserta didik selama proses pembelajaran berlangsung yaitu peserta didik aktif bertanya, peserta didik menunjukkan rasa empati yang sangat baik kepada teman yang tidak bisa menjawab, memberikan respons yang baik tehadap jawaban dari peserta didik lain, komunikasi yang terjalin baik antara peserta didik dengan teman dan peserta didik dengan guru, bersemangat ketika mengikuti pembelajaran dan sangat antusias ketika model pembelajaran diterapkan karena guru sudah cukup memotivasi peserta didik dengan baik.

\section{SIMPULAN}

Penerapan model Fan N Pick dan Inside Outside Circle terbukti dapat meningkatkan keterampilan sosial peserta didik kelas V SD Negeri Banyuajuh 2 Kamal. Hal ini terbukti dari hasil observasi keterampilan sosial peserta didik selama dua siklus. Hasil peningkatan keterampilan sosial meningkat pada lima aspek, yaitu kerjasama, ketegasan, empati, tanggung jawab, dan pengendalian diri. Dari hasil observasi keterampilan sosial peserta didik yang telah diisi oleh kedua observer pada lembar observasi yang telah disediakan memperoleh data yaitu pada siklus I memperoleh hasil sebesar 74.2\% yang menunjukkan kriteria baik, sedangkan pada siklus II memperoleh hasil sebesar $81.8 \%$ dengan kriteria sangat baik. Hal ini dapat dilihat dari perubahan peserta didik selama proses pembelajaran berlangsung yaitu peserta didik aktif bertanya, peserta didik menunjukkan rasa empati yang sangat baik kepada teman yang tidak dapat menjawab, memberikan respons yang baik terhadap jawaban dari peserta didik lain, dan komunikasi yang terjalin baik antara peserta didik dengan teman dan peserta didik dengan guru. Model 
Fan N Pick dan Inside Outside Circle dapat diterapkan oleh guru sebagai alternatif dalam meningkatkan keterampilan sosial peserta didik dan hasil belajar. Pemilihan model pembelajaran juga harus disesuaikan dengan materi pembelajaran, alokasi waktu yang ditetapkan, jumlah peserta didik dan penggunaan ruang kelas atau pembelajaran di luar kelas.

\section{DAFTAR RUJUKAN}

Asoodeh, M. H., Asoodeh, M. B., \& Zarepour, M. (2012). The Impact of Student - Centered Learning on Academic Achievement and Social Skills. Procedia - Social and Behavioral Sciences, 46, 560-564. https://doi.org/10.1016/j.sbspro.2012.05.160

Aziz, M. J. A., Jilani, J., Shukur, Z., Razali, R., Jailani, N., \& Bakar, M. A. (2014). Student Centered Learning Environment for Project Monitoring. Procedia Technology, 11(Iceei), 940-949. https://doi.org/10.1016/j.protcy.2013.12.279

Bernero, J. (1992). Using Cooperative Learning Strategies. Nurse Educator, 17(4), 37-40. https://doi.org/10.1097/00006223199207000-00016

Effendi, A., Soetjipto, B. E., \& Widiati, U. (2016). The Implementation of Cooperative Learning Model TSTS and Carousel Feedback to Enhance Motivation and Learning Outcome for Social Studies. Journal of Research \& Method in Education (IOSR-JRME), 6(3), 131-136. https://doi.org/10.9790/7388-060304131136

Frianto, Soetjipto, B. E., \& Amirudin, A. (2016). The Implementation of Cooperative Learning Model Team Game Tournament and Fan N Pick to Enhance Motivation and Social Studies Learning Outcomes. IOSR Journal of Humanities and Social Science, 21(5), 74-81. https://doi.org/10.9790/0837-2105077481

Gresham, F. M., Elliott, S. N., Vance, M. J., \& Cook, C. R. (2011). Comparability of the Social Skills Rating System to the Social Skills Improvement System: Content and Psychometric Comparisons Across Elementary and Secondary Age Levels. School Psychology Quarterly, 26(1), 27-44. https://doi.org/10.1037/a0022662

Kagan, S. \& Kagan, M. (2009). Kagan Cooperative Learning. San Clemente: Kagan Publishing.

Kaufman, D. B., Felder, R. M., \& Fuller, H. (2000). Accounting for Individual Effort in Cooperative Learning Teams. The Research Journal for Engineering Education, 89(2), 133-140. https://doi.org/10.1002/j.2168-9830.2000.tb00507.x

Marioara, L. (2015). The Education Change for in Need Student-Centered Learning. Procedia - Social and Behavioral Sciences, 191, 2342-2345. https://doi.org/10.1016/j.sbspro.2015.04.562

Purwaningrum. (2017). Penerapan Model Pembelajaran Kooperatif Quiz-Quiz Trade dan Inside Outside Circle untuk Meningkatkan Keterampilan Sosial dan Hasil Belajar Siswa Kelas IV SDN Pandanwangi 2 Malang. Tesis tidak diterbitkan. Universitas Negeri Malang, Malang.

Riyadi, B. A., Soetjipto, B. E., \& Amirudin, A. (2016). The Implementation of Cooperative Learning Model Fan-N-Pick and Quick on the Draw to Enhance Social Competence and Cognitive Learning Outcome for Social Studies. IOSR Journal of Humanities and Social Science, 21(4), 90-96. https://doi.org/10.9790/0837-2104019096

Taufiqurrahman. (2018). Peningkatan Keterampilan Sosial dan Hasil Belajar Siswa Kelas V Melalui Penerapan Model Pembelajaran Numbered Head Together dan Fan N Pick di SDN Gontor Kabupaten Ponorogo. Tesis tidak diterbitkan. Universitas Negeri Malang, Malang.

Tyabaev, A. E., Sedelnikova, S. F., \& Voytovich, A. V. (2015). Student-Centered Learning: The Experience of Teaching International Students in Russian Universities. Procedia - Social and Behavioral Sciences, 215(June), 84-89. https://doi.org/10.1016/j.sbspro.2015.11.578 